\title{
Low Land Ecosystem Rain Fed Rice (Oryza Sativa L.) Variety Adaptation at Assosa, Western Ethiopia
}

\author{
Addisu Dereje ${ }^{1, \text { * }}$, Hailemariam Solomon ${ }^{2}$ \\ ${ }^{1}$ Department of Plant Breeding, Assosa Agricultural Research Center, Assosa, Ethiopia \\ ${ }^{2}$ Department of Plant Breeding, Melkasa Agricultural Research Center, Melkasa, Ethiopia
}

Email address:

Adisudereje2018@gmail.com (A. Dereje)

${ }^{*}$ Corresponding author

To cite this article:

Addisu Dereje, Hailemariam Solomon. Low Land Ecosystem Rain Fed Rice (Oryza Sativa L.) Variety Adaptation at Assosa, Western Ethiopia. Ecology and Evolutionary Biology. Vol. 4, No. 1, 2019, pp. 11-14. doi: 10.11648/j.eeb.20190401.12

Received: May 17, 2019; Accepted: July 8, 2019; Published: July 26, 2019

\begin{abstract}
Benishangul Gumuze is one of the most important potential rice producing areas in Ethiopia. Six improved lowland ecosystem rice varieties were evaluated with the objective of selecting adapted lowland ecosystem rice varieties for Assosa condition. The trial was conducted at Assosa Agricultural Research Center during 2017/18 and 2018/19 cropping season using Randomized Complete Block Design at low land ecosystem. The size of the plot was $1.5 \mathrm{~m} \times 5 \mathrm{~m}$ with gap of $0.5 \mathrm{~m}$ between plot and $1.5 \mathrm{~m}$ between blocks. Data was collected from nine agronomic parameters such as days to $50 \%$ heading days to $85 \%$ physiological maturity, plant height, panicle length number of fertile tillers, number of non-fertile tiller, number of filled grain per panicle, number of unfilled grain per panicle, and grain yield ( $\mathrm{kg} / \mathrm{ha})$ and ranged 93 to 110,148 to 157,80 to 98 , 19 to $21,4.8$ to $6.1,0.43$ to $0.78,82$ to 109,10 to $29,2001.4$ to 2908.6 respectively. The mean combined analysis of two years showed that some agronomic parameters were statically highly significant different $(p<0.05)$ while other parameters showed non-significant different. The mean square of over the year revealed that the yield $(\mathrm{kg} / \mathrm{ha})$ was highly significant different and other agronomic parameters showed the same result which have high contribution in yield increment of rice production. Among six tested rice varieties, Edeget and Demoze scored the highest grain yield $(2908.6 \mathrm{~kg} / \mathrm{ha})$ and $(2496.8 \mathrm{~kg} / \mathrm{ha})$ respectively. Therefore, based on objectively measured agronomic traits Edeget and Demoze were best adapted to low land rain fed rice ecosystem of Assosa until superior varieties will be investigated.
\end{abstract}

Keywords: Rice, Lowland Ecosystem, Agronomic Traits, Grain Yield

\section{Introduction}

Rice (Oryza sativa L.) is a plant belonging to the family of grasses, Poaceae (formerly known as Gramineae). It is second three major food crops of the world (Rice, Maize and Wheat) and forms the staple diet of about half of the world's population [12]. In Africa, rice is becoming increasingly popular, important stable food crop and it is grown over $75 \%$ of the countries [12]. This crop is recognized in Ethiopia as a food security crop and also a source of income and employment opportunities. It grows on $0.27 \%(33,819.65$ hectares) of production area with a total production of $0.37 \%(923,627.30$ quintals $)$ in different regions of Ethiopia [2]. It is estimated that about 30 million hectares are suitable for rice production [3]. The rice research has focused mainly on the introduction of improved varieties from a range of different sources, including the International Rice Research Institute (IRRI), the Africa Rice Center (WARDA), Guinea and Madagascar.

Rice can grow at different agro ecological zones and the main types of ecosystems are rain fed upland; rain fed low land and flooded prone areas. There are also five distinct ecosystems which include irrigated rice ecosystems, flooded prone rice ecosystems, deep water and floating rice along river beds / banks [7].

Benishangul Gumuze is one of the most potential rice producing areas in Ethiopia. Even though, rice research in Ethiopian is in progress, within a few years promising varieties have been released and distributed to end users [9, 10]. It was estimated that the crop can be cultivated on about 4.9 million hectares of land under rain fed conditions. 
Higher grain yield and increased yield stability across a range of environments are needed for rice farmers, who typically harvest yields of $0.9-2.4 \mathrm{t} / \mathrm{ha}$ in rained lowland fields and 0.6-1.5t/ha in upland fields [5] Adaptation and performance of the released upland rice genotypes were evaluated at upland ecosystems of the study area (Assosa Agricultural Research Center Kamash sub center [6]) but not evaluated under lowland ecosystems because it is on progress. This study therefore, is focused on adapting and evaluating of low land rice varieties under lowland condition.

\section{Materials and Methods}

The study was conducted in western part of Ethiopia in Benishangul Gumuze region which is the most potential rice growing area. Benishangule Gumuze Regional State is found at $687 \mathrm{~km}$ away from the capital city of the country, Addis Ababa, in the west. The region is bordered with the Sudan in the west, Amhara Regional state in the east and north, Oromiya Regional state in the east and south east and Gambella Regional state in the south. Its specific location is Assosa Agricultural Research Center which is located at $10^{\circ}$ $002^{\prime} .922^{\prime \prime} \mathrm{N}$ latitude and $34^{\circ} 33$ '.868" E longitude. The altitude and annual rain fall of the study area is $1547 \mathrm{~m}$ above sea level and $1133.1 \mathrm{~mm}$ respectively [1].
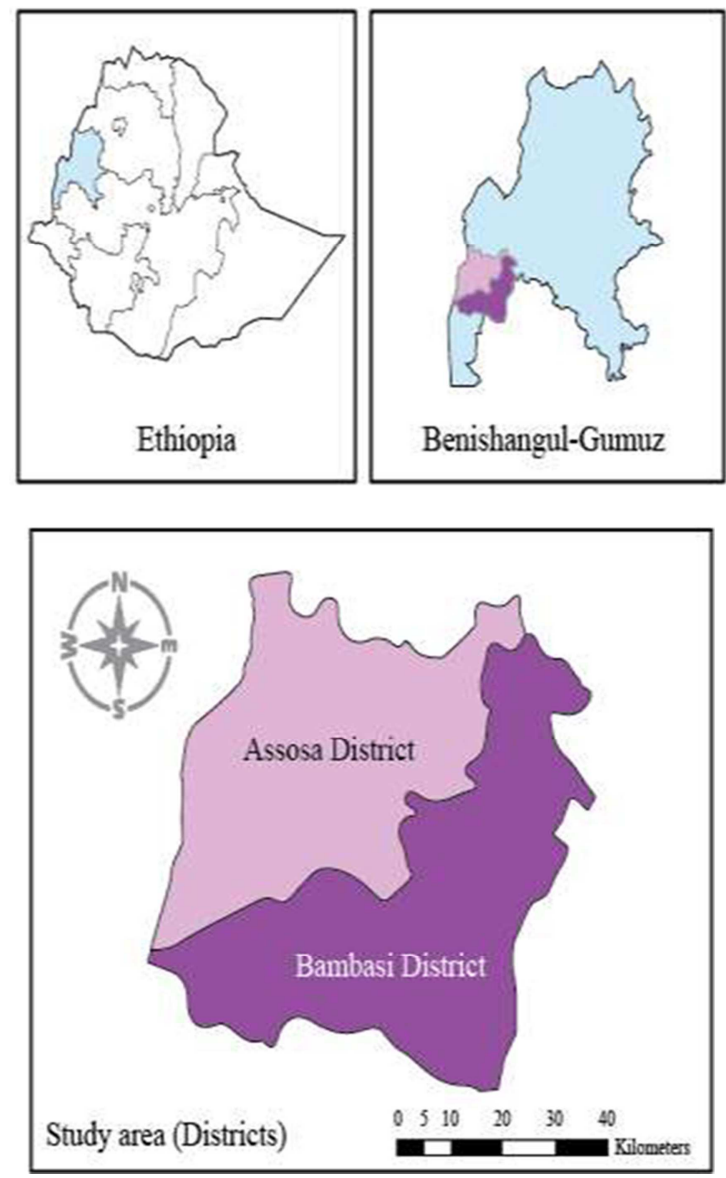

Figure 1. Map of the study area.
The tested materials were obtained from the National Rice Research Coordinating Center and a total of six lowland improved rice varieties namely; Ediget, Hibber, Gumera, Xjigna, and Fogera-2 were evaluated for their adaptability for two years under low land condition. The trial was conducted in randomized complete design with four replication. The size of the plot was measured $7.5 \mathrm{~m}^{2}(1.5 \mathrm{~m} \times 5 \mathrm{~m})$ with the gap of 0.5 between plot and $1.5 \mathrm{~m}$ between blocks.

Sowing was done by row planting at seed rate of $60 \mathrm{~kg} / \mathrm{ha}$ within the first week of June and last week of July in 2017/18 and 2018/19 cropping season. All other recommended agronomic practices were kept normal and uniform to ensure normal plant growth and development. Seed yield of each plot was recorded and then converted into $\mathrm{kg} / \mathrm{ha}$.

Data on plant height $(\mathrm{PH})$, panicle length (PL), days to $50 \%$ heading $(\mathrm{DH})$, days to $85 \%$ physiological maturity (DPM), number of fertile tillers (NFT), number of non-fertile tiller (NNFT), number of filled grain per panicle (NFG), number of unfilled grain per panicle (NUFG) and grain yield (GY). Were collected and subject to statistical analysis using SAS statistical software (SAS institute 2002) [8].

The grain yield (GY) in (gm.) was determined by harvesting all plants from the central four rows of each plot. Seeds were also adjusted to a moisture level of $14 \%$ using moisture content tester and then converted into $\mathrm{kg}$ ha- 1 . The whole data were recorded from the same ten pre tagged sampled plants and from the middle of four rows of each plot [8].

\section{Result and Discussion}

Adaptability of six low land rice ecosystems was evaluated for two years at Assosa Agricultural Research Center. Analysis of variance showed that some tasted agronomic parameters were statically significant during the first and the second year (2017/18 and 2018/19) while other agronomic parameters non-significant (Table 1 and 2). The significance difference of varieties indicates the presence of genetic variability for each of the characters among the tested varieties and possibility of manipulating these variations for improvement [4].

Day's to $50 \%$ heading (DH), days to $85 \%$ physiological maturity (DPM), plant height $(\mathrm{PH})$, number of filled grain per panicle (NFG) and number of unfilled grain per panicle (NUFG) were highly significant different while number of fertile tiller per plant (NFT), number of non- fertile tiller per plant (NNFT) and grain yield (GYD) were non-significant different during 2017/18 cropping season. (Table 1). In the second cropping season, also few agronomic parameters showed highly significant different /Days to $50 \%$ heading (DH), days to $85 \%$ physiological maturity (DPM), plant height and grain yield (GYD)/ while others showed nonsignificance different. (Table 2) similar result was reported by [6]. 
Table 1. Mean table of six low land rice varieties evaluated for their grain yield ( $\mathrm{kg} / \mathrm{ha}$ ) and other agronomic parameters at Assosa, $2017 / 18$.

\begin{tabular}{|c|c|c|c|c|c|c|c|c|c|c|}
\hline No & VARIETIES & DH & DPM & PH & PL & NFT & NNFT & NFG & NUFG & GY \\
\hline 1 & EDIGET & 90.00 & 144.50 & 99.62 & 21.175 & 4.85 & 0.80 & 108.70 & 15.05 & 3632.40 \\
\hline 2 & HIBBER & 92.25 & 146.75 & 92.28 & 21.065 & 4.45 & 1.00 & 88.35 & 11.95 & 2380.90 \\
\hline 3 & DEMOZE & 97.00 & 146.75 & 99.38 & 20.855 & 4.60 & 1.25 & 91.55 & 9.75 & 2311.60 \\
\hline 4 & GUMERA & 97.50 & 147.75 & 93.96 & 21.275 & 5.25 & 0.90 & 113.90 & 21.80 & 2263.60 \\
\hline 5 & X-JIGNA & 96.75 & 145.25 & 93.12 & 21.82 & 5.10 & 1.05 & 94.45 & 19.70 & 1592.80 \\
\hline \multirow[t]{3}{*}{6} & FOGERA-2 & 114.50 & 153.75 & 82.12 & 20.36 & 5.25 & 0.85 & 84.45 & 22.05 & 1752.50 \\
\hline & Mean & 98.00 & 147.46 & 93.41 & 21.092 & 4.9167 & 0.975 & 96.9 & 16.717 & 2322.30 \\
\hline & $\operatorname{LSD}(0.05)$ & 1.52 & 3.9614 & 17.19 & 3.6277 & 1.122 & 0.6548 & 62.379 & 12.62 & 683.38 \\
\hline
\end{tabular}

Table 2. Mean table of six low land rice varieties evaluated for their grain yield ( $\mathrm{kg} / \mathrm{ha}$ ) and other agronomic parameters at Assosa, $2018 / 19$.

\begin{tabular}{|c|c|c|c|c|c|c|c|c|c|c|}
\hline No & VARIETIES & DH & DPM & PH & PL & NFT & NNFT & NFG & NUFG & GY \\
\hline 1 & EDIGET & 96 & 151.5 & 90.6 & 18.75 & 6.05 & 0.05 & 94.25 & 9.05 & 2184.8 \\
\hline 2 & HIBBER & 97.25 & 160.75 & 86.75 & 18.35 & 5.2 & 0.55 & 76.65 & 9.25 & 1901.3 \\
\hline 3 & DEMOZE & 100.75 & 159.5 & 97.75 & 19.15 & 7.65 & 0.15 & 116.45 & 11.55 & 2682.1 \\
\hline 5 & X-JIGNA & 96.5 & 153 & 97.6 & 19.38 & 5.7 & 0.2 & 124.25 & 16.05 & 2537.6 \\
\hline \multirow[t]{3}{*}{6} & FOGERA-2 & 106 & 161.25 & 79.03 & 19.44 & 6.6 & 0.25 & 123.8 & 37 & 2250.2 \\
\hline & Mean & 99.25 & 156.33 & 91.61 & 19.37 & 6.25 & 0.23 & 102.14 & 17.5 & 2303.11 \\
\hline & $\operatorname{LSD}(5 \%)$ & 3.92 & 1.99 & 6.58 & 1.9 & 1.73 & 0.38 & 22.31 & 6.83 & 809.32 \\
\hline
\end{tabular}

The mean combined analysis of variance for two years revealed that some parameters Days to $50 \%$ heading (DH) and number of unfilled grain per panicle (NUFG) were highly significant different, other parameter were significant different and the rest were non- significant different $(\mathrm{P} \leq$ 0.05) [10].. The mean grain yield of two years cropping season indicates that Edeget and Demoze were best performing varieties compared to other tasted varieties. Edeget has both shortest $85 \%$ physiological maturity period (148) and days to $50 \%$ heading (93) in addition to high grain yield (2908.60 kg/ha) (Table 3$)$.

Demoze has longest $85 \%$ physiological maturity period preceded by Fogera-2 and Hebber while Edeget has the shortest one (148) Days to 50\% heading showed highly significant different among all varieties ranging from 93 to 110 days and days to maturity which ranged between 148 to 157 days. Plant height also showed highly significant different among all varieties. It ranged 80.57 to $98.56 \mathrm{~cm}$ (Fogera-2 and Demoze) respectively (Table 3 ).

The number of panicle length ranged from 19.71 to
$21.21 \mathrm{~cm}$ (Edeget and Gumera) respectively. Number of filled grain per panicle was the most important agronomic traits which plays great role in yield increment but it was nonsignificant different statically.

The highest number of filled grain per panicle (109.35) was recorded in X-jigna followed by fogera-2 (104.130). Grain yield of varieties ranged from 2001.42 to 2908.60 $\mathrm{kg} / \mathrm{ha}$ with an average value of $2312.71 \mathrm{~kg} /$ ha (Table 3 ). The study showed that Edeget and Demoze had best adapted to low land ecosystem of Assosa in terms of grain yield.

The effect of year $\mathrm{x}$ treatment interaction for grain yield, days to $85 \%$ heading, and days to $85 \%$ physiological maturity was statically highly significant variation $(\mathrm{p}<0.05)$ (Table 4). All tasted parameters indicate non- significant variation except grain yield which was highly significant within replication through the year (Table 4). Number of fertile tiller (NFT) was also indicates highly significant variation through the year which has high contribution in yield increment of rice production $[4,11]$.

Table 3. Combined Mean value of low land rice adaptation varieties 2017/18 and 2018/19 cropping season.

\begin{tabular}{|c|c|c|c|c|c|c|c|c|c|}
\hline VARIETIES & DH & DPM & $\mathbf{P H}$ & PL & NFT & NNFT & NFG & NUFG & GY \\
\hline EDIGET & 93.00 & 148.00 & 95.11 & 19.96 & 5.45 & 0.43 & 101.48 & 12.05 & 2908.60 \\
\hline HIBBER & 94.75 & 153.75 & 89.52 & 19.71 & 4.83 & 0.78 & 82.50 & 10.60 & 2141.10 \\
\hline DEMOZE & 98.88 & 153.13 & 98.56 & 20.00 & 6.13 & 0.70 & 104.00 & 10.65 & 2496.80 \\
\hline GUMERA & 98.25 & 149.88 & 95.95 & 21.21 & 5.78 & 0.53 & 95.68 & 21.95 & 2263.20 \\
\hline X-JIGNA & 96.63 & 149.13 & 95.36 & 20.60 & 5.40 & 0.63 & 109.35 & 17.88 & 2065.20 \\
\hline FOGERA-2 & 110.25 & 157.50 & 80.57 & 19.90 & 5.93 & 0.55 & 104.13 & 29.53 & 2001.40 \\
\hline Range & $93.00-110.25$ & $148.00-157.89$ & $80.57-98.56$ & $19.71-21.21$ & $4.83-6.13$ & $0.43-0.78$ & $82.50-109.35$ & $10.60-29.53$ & $2001.40-2908.60$ \\
\hline $\mathrm{CV}$ & 3.47846 & 3.688027 & 9.085509 & 10.21566 & 23.34767 & 89.39493 & 34.49945 & 42.25296 & 27.42347 \\
\hline $\operatorname{LSD}(0.05)$ & 3.4696 & 5.6655 & 8.5004 & 2.0901 & 1.3184 & 0.5425 & 34.724 & 7.3108 & 641.42 \\
\hline
\end{tabular}


Table 4. Interaction (Mean square) of combined low land variety adaptation over the year (2017/18 and 2018/19).

\begin{tabular}{|c|c|c|c|c|c|c|c|c|c|}
\hline & DH & DPM & $\mathbf{P H}$ & PL & NFT & NNFT & NFG & NUFG & GY \\
\hline YEAR & $18.75 *$ & $945.1875^{* *}$ & $38.736133^{\mathrm{ns}}$ & $\begin{array}{l}35.63853333 * \\
*\end{array}$ & $\begin{array}{l}21.33333333 * \\
*\end{array}$ & $6.75 * *$ & $329.700833^{* *}$ & $7.363333^{\mathrm{ns}}$ & $4416.963^{\mathrm{ns}}$ \\
\hline TRT & $297.6^{* *}$ & $\begin{array}{l}101.2708333 \\
* *\end{array}$ & $\begin{array}{l}343.795913 * \\
*\end{array}$ & $2.57158^{\mathrm{ns}}$ & $1.71733333^{\mathrm{ns}}$ & $0.128^{\mathrm{ns}}$ & $713.906833^{\mathrm{ns}}$ & $\begin{array}{l}460.573333 * \\
*\end{array}$ & $926488.143^{\mathrm{ns}}$ \\
\hline REP & $4.75^{\mathrm{ns}}$ & $6.0763889^{\mathrm{ns}}$ & $29.157256^{\mathrm{ns}}$ & $1.56842222^{\mathrm{ns}}$ & $0.40222222^{\mathrm{ns}}$ & $0.28666667^{\mathrm{ns}}$ & $1497.611944_{\mathrm{ns}}$ & $89.245556^{\mathrm{ns}}$ & $\begin{array}{l}2420197.543 * \\
*\end{array}$ \\
\hline $\begin{array}{l}\text { REP } \\
\text { (YEAR) }\end{array}$ & $14.305556^{*}$ & $3.4097222^{\mathrm{ns}}$ & $66.003533^{\mathrm{ns}}$ & $3.25051111^{\mathrm{ns}}$ & $3.01555556^{* *}$ & $0.07222222^{\mathrm{ns}}$ & $2509.976389^{\mathrm{ns}}$ & $37.156667^{\mathrm{ns}}$ & $357264.431^{\mathrm{ns}}$ \\
\hline YEAR*TRT & $56.1 * *$ & $27.7375 * *$ & $56.298813^{\mathrm{ns}}$ & $2.07555333^{\mathrm{ns}}$ & $1.56933333^{\mathrm{ns}}$ & $0.098^{\mathrm{ns}}$ & $1826.366833^{\mathrm{ns}}$ & $111.905333^{*}$ & $\begin{array}{l}1440405.486 * \\
*\end{array}$ \\
\hline
\end{tabular}

$* *=$ highly significant different, ${ }^{*}=$ significant different, $\mathrm{ns}=$ non-significant different

\section{Conclusion and Recommendation}

Research institutions and other private sectors need to pay attention to the research and development and adaptive lowland rice varieties for the region. It is better to pay adequate attention to introduce and practice best adapted lowland rice ecosystem to insure food security.

The combined analysis of variance for low land rice adaptation which was conducted for two consecutive years indicated that some important tasted agronomic parameters were highly significant different statically. The study showed that some tested rice varieties were indicating their adaptability to lowland ecosystem of Assosa condition. However, when we consider in terms of grain yield $(\mathrm{kg} / \mathrm{ha})$ Edeget and Demoze scored the highest grain yield (2908.60 $\mathrm{kg} / \mathrm{ha})$ and $(2496.80 \mathrm{~kg} / \mathrm{ha})$ respectively.

Therefore, based on the result obtained from the research after two years we were interested to recommend Edeget and Demoze for wider cultivation for lowland rice ecosystem of Assosa until superior varieties will be investigated.

\section{Acknowledgements}

We would like to express our sincere gratitude to Fogera National Rice Research and Training Center who provided us with tasted materials, financial support and other valuable cooperation. Our sincere appreciation also goes to our technical assistances especially Yesuf Indris and daily laborers because without their tireless efforts this result would not have been realized.

\section{References}

[1] National Meteorological Service Agency, 2010.

[2] Central Statistical Authority. 2013. Agricultural Sample Survey Report on Area and Production for Major Crops
(Private Peasant Holdings 'Meher" season), CSA, Addis Ababa, Ethiopia.

[3] MoARD (Ministry of Agriculture and Rural Development), (2010). NARRDS (national rice research and development strategy). Addis Ababa, Ethiopia.

[4] Taddesse L., Ketema B. and Wondimu B. 2015. Genotypic variation and trait association in nitrogen use efficiency of upland rice varieties in north-western Amhara region, Ethiopia. Int. J. Res. ISSN: 2349-9788.

[5] Singh VP, Singh RK. 2000. 'Rainfed rice: a source book of best practices and strategies in Eastern India.' (International Rice Research Institute: Los Baños).

[6] Alemu Dabi, Assefa Gidesa. Evaluation of Improved Upland Rice Varieties for Potential Rice Producing Area Kemashi Zone of Benishangul Gumze of Ethiopia. Ecology and Evolutionary Biology. Vol. 1, No. 1, 2016, pp. 1-6. doi: 10.11648/j.eeb.20160101.11.

[7] Prasad, G. S. V., Muralidharan K., Rao C. S. and Prasad A. S. R., 2001. Stability and Yield Performance of Genotypes: A Proposal for Regrouping World Rice Area into Mega Environments. Current Science. 81 (10): 1337-1346.

[8] Solomon H, Wegary D. Phenotypic correlation and path coefficient analysis of yield and yield component in rice (Oryza Sativa). Int J Res Rev. 2016; 3 (7): 1-5.

[9] EAIR (Ethiopian Institute of Agricultural Research). 2011. Challenges and Opportunities of Rice in Ethiopian Agricultural Development. ISBN: 978-99944-53-75-7.

[10] Hailemariam Solomon May 2014 M.Sc thesis latest version 2 (1) rice Haramaya university Ethiopia, performance and farmers evaluation of upland rice (Oryza Sativa L) genotypes under upland and lowland ecology of North-Western Ethiopia (unpublished).

[11] Sanghera G. S., Kashyap S. C. and Parray G. A. 2013. Genetic variation for grain yield and related trait temperate red rice (Oryza sativa L.) Ecotypes. J. Sci Biol, 5 (3): 1-7.

[12] FAO, 2013 http:www.fao.org/economic/puplications/ricemarket-monitor-rmm/en/(accessed date June, 2013). 